\title{
Who is Responsible for Decision-making in Participatory Development? - Lessons Learned from the Social Reconstruction Plan for the Nam Theun 2 Dam Project
}

\author{
Saki Ando* \\ Dept. of International Studies, Graduate School of Frontier Sciences, \\ The University of Tokyo \\ 5-1-5 Kashiwanoha, Kashiwa, Chiba 2778563, Japan \\ Tel: 81-4-7136-4874Ｅ-mail: saki.ando0@gmail.com \\ Maiko Sakamoto (Corresponding author) \\ Dept. of International Studies, Graduate School of Frontier Sciences, \\ The University of Tokyo \\ 5-1-5 Kashiwanoha, Kashiwa, Chiba 2778563, Japan \\ Tel: 81-4-7136-4874Ｅ-mail: m-sakamoto@k.u-tokyo.ac.jp
}

Bounsouk Souksavath

Faculty of Engineering, National University of Laos

P.O.BOX:3166, Lao-Thai Friendship road, Vientiane

Tel: 856-21-351926Ｅ-mail: bounsoukk@yahoo.co.uk

Received: May 17, 2017 Accepted: June 2, 2017 Published: July 10, 2017

doi:10.5296/jad.v3i2.11240 URL: https://doi.org/10.5296/jad.v3i2.11240

*) Affiliation is as of the time research was conducted. Current affiliation is PwC Consulting LLC, Marunouchi Park Bldg. 21st Floor, 2-6-1 Marunouchi, Chiyoda-ku, Tokyo 100-6921. 


\title{
II Macrothink
}

\begin{abstract}
The livelihood reconstruction plan implemented in villages affected by the Nam Theun 2 Dam has been facing the limited sustainability of resource use and increasing economic and social disparity among the 16 relocated villages. The objective of this paper is to describe the problems that arose despite a carefully planned resettlement scheme, which included the participation of the residents from affected villages. Issues can be categorized into three types, based on whether risks were identified before decision-making and whether appropriate mitigation measures were considered for the identified risks. Local consensus may not be in agreement with development goals, and the issues that can be addressed by local consultation are limited. Therefore, whether to use local consultation or not should be considered carefully.
\end{abstract}

Keywords: dam, resettlement, livelihood reconstruction, Laos, remote sensing 


\section{Introduction}

Until the late 20th century, large dams had been accepted as one of the most efficient ways to meet a growing demand for water and energy. The construction of large dams had been regarded as a symbol of modernization, bringing development and economic progress. Although the cost of construction was enormous, immediate and significant benefits justified the investment and associated social and environmental impacts. However, the cumulative experience of large dam development has revealed the overall costs of large dams, which has emerged as a serious public concern.

To assess prior performance and learn lessons from previous projects, the World Commission on Dams (WCD) conducted a broad review of past large dam development projects. Based on this analysis, five core values for decision-making related to large dam projects were proposed (WCD, 2010):

- Equity: equity of benefits and losses among the stakeholders to ensure that no one bears only the burdens, or vice versa.

- Efficiency: efficiency compared to other options, including alternatives to dams.

- Participatory decision-making: agreement among people affected by proposed construction projects, especially ethnic minority groups.

- Sustainability: projects are both financially and environmentally sustainable.

- Accountability: the decision-making process is transparent.

The Nam Theun 2 (NT2) Multipurpose Hydroelectric Dam Project in Lao PDR was heralded as the first project to implement the proposals of the WCD and has been operated by the Nam Theun 2 Power Company (NTPC). The project introduced a number of measures to mitigate the negative effects of dam construction on local communities and the environment.

In regard to equity, local villagers affected by the project received compensation to reconstruct their livelihoods after resettlement. In addition, profits from the NT2 dam are allocated to the national budget for education and local development. With respect to efficiency, although cancelling the dam construction project was not an option, several options were considered to balance the social and environmental impacts and estimated profits. Several local consultations were conducted for the purpose of selecting sites for resettlement as a process of participatory development. Special attention was paid to ethnic minorities while creating the Social Development Plan (Nam Theun 2 Power Company [NTPC], 2005). In order to promote sustainability, a sustainable income portfolio was planned. Furthermore, village organizations, such as the Village Forestry Association and the Village Fishery Group, were established for long-term sustainable management of resources. With regard to accountability, the Concession Agreement, which is a legal document to define the obligations of both the NTPC and the Government of Laos, was made public. In addition, the World Bank and the Government of Laos send regular monitoring teams to oversee the progress. 
The NT2 Hydropower Project adopted an advanced social action program, namely the Social Development Plan, to improve the lives of local residents after relocation. Infrastructure, such as houses and schools, was provided in the resettlement area, as were programs to promote livelihood adjustment. The failures in the livelihood reconstruction program have been pointed out despite the careful planning, and a doubt has been cast about the sustainability of current approaches to livelihood adjustment (Matsumoto \& Harashina, 2012; Mcdowell et al., 2015). There also exists a problem of expanding economic disparity among villages and households (WB, 2014). On the other hand, compensation has improved average income in all the resettled villages.

The purpose of this paper is to examine the critical success and failure factors in applying the proposed WCD model in practice, based on experiences from the NT2 multipurpose dam project. In particular, this study focuses on the limitations of and ethical concerns with using participatory development schemes in decision-making.

\section{Materials and Methods}

\subsection{Nam Theun 2 Project}

The study area is shown in Figure 1. The NT2 Dam is located in the central part of Lao PDR. Construction started in 2005 and commercial operation began in 2010. Because of dam construction, 5,317 people and 977 households from 17 villages were forced to move to 16 villages following inundation in 2008. The villagers relocated to the newly established resettlement area on the south rim of the reservoir with keeping their household composition in each village, except for one merged village (Cay Oy). Table 1 shows the summary of the general information about the 16 villages (listed according to geography, starting from the most northern location). Twenty-one ethnic minority groups lived in this area, with a traditional livelihood based on slash-and-burn agriculture supplemented by the collection of non-timber forest products (NTFP), fishing, and the sale of livestock. In order to compensate for the loss of access to these natural resources, the project authority drew up the Social Development Plan consisting of five pillars: agriculture, fishery, livestock, forestry, and off-farm income sources, including handicrafts, bike repair, and small shops. In addition to compensation for inundated land and assets, various types of support intended to improve the standard of living in the resettlement area were also to be provided. The project authority planned that agriculture would become the major income source and to support this activity, plots of 0.66 ha of farmland were assigned to each household. For fishery, one boat was allocated to every two households; for livestock, cattle were to be provided to each household; for forestry, the forestry association was formed and it provided a dividend in return for labor every year. Furthermore, basic infrastructure, houses, wells, schools, and village halls were to be constructed. Most of the compensation measures outlined in the plan were provided. Figure 2 shows the income structure and the differences from village to village, although there are some regional tendencies such as a higher income from fishery and other sources (non-farming small business) in northern and central villages and a higher proportion of agricultural income in southern villages. 


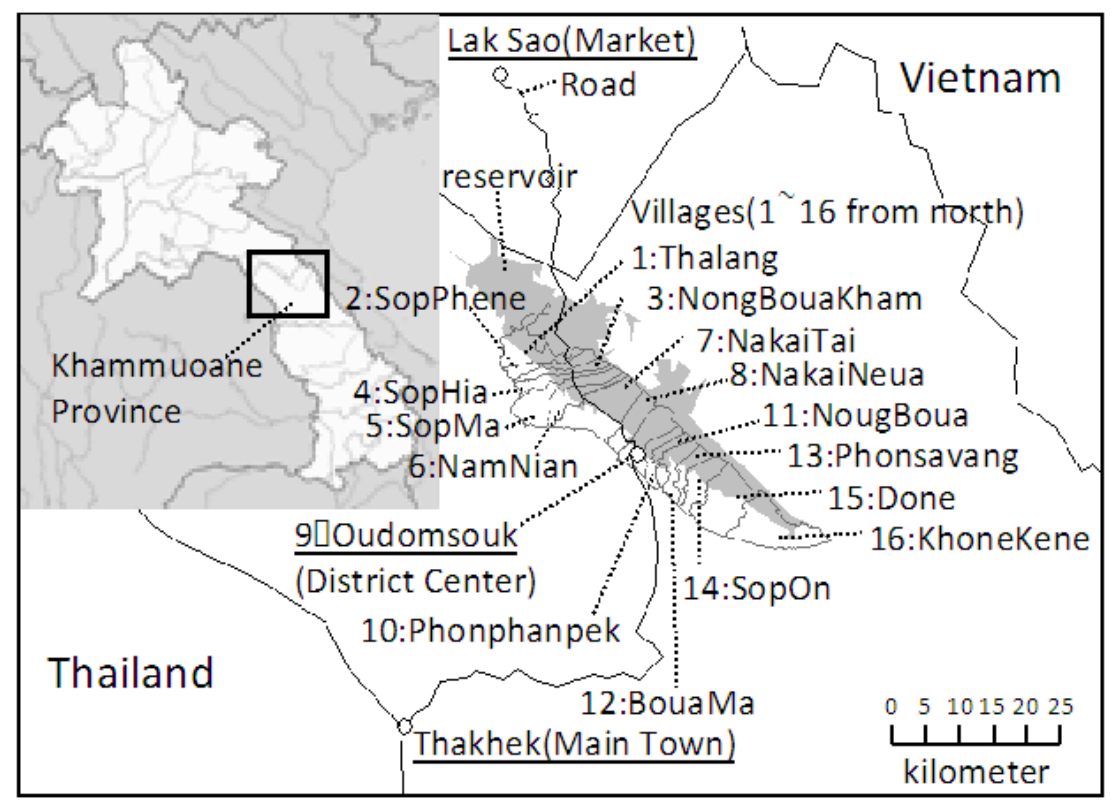

Figure 1. Study area (based on the project authority, 2005)

Table 1. General Information on Resettled Villages

\begin{tabular}{|c|c|c|c|c|c|c|c|c|}
\hline & & \multirow{2}{*}{$\begin{array}{l}\text { Majority } \\
\text { Ethnicity }\end{array}$} & \multicolumn{3}{|c|}{ \# of Households } & \multirow{2}{*}{$\begin{array}{l}\text { Relocation } \\
\text { Distance } \\
(\mathrm{km})\end{array}$} & \multirow{2}{*}{$\begin{array}{r}\text { Literacy } \\
2005\end{array}$} & \multirow{2}{*}{$\begin{array}{l}\text { Period of } \\
\text { Village } \\
\text { Formation }\end{array}$} \\
\hline & & & 1998 & 2003 & 2014 & & & \\
\hline 1 & Thalang & Tai & 52 & 64 & 119 & 0.5 & 41.7 & Recent \\
\hline 2 & Sop Phene & Bo & 43 & 51 & 57 & 12.2 & 18.1 & Old \\
\hline 3 & Nongbouakham & Tai & 42 & 45 & 73 & 2.9 & 59.8 & Recent \\
\hline 4 & Sop Hia & Tai/Vietic & 37 & 55 & unknown & 23 & 41.5 & Mixed \\
\hline 5 & Sop Ma & Bo & 47 & 63 & 73 & 10.6 & 17.8 & Old \\
\hline 6 & Namnian & Tai & 16 & 25 & 68 & 23 & 34.4 & Mixed \\
\hline 7 & Nakai Tai & Bo/Vietic & 147 & 174 & 236 & 0.6 & 22.9 & Mixed \\
\hline 8 & Nakai Neua & Bo & 67 & 85 & 127 & 0.9 & 56 & Recent \\
\hline 9 & Oudomsouk & Mixed & 285 & 300 & 547 & - & 62.5 & Recent \\
\hline 10 & Phonephanpek & Mixed & 85 & 99 & 126 & - & 39.8 & Recent \\
\hline 11 & Nong Boua & Makong/Bo & 28 & 30 & 43 & 1.8 & 17.1 & Old \\
\hline 12 & Boua Ma & Makong & 55 & 65 & 93 & 2.0 & 21.6 & Old \\
\hline 13 & Phonesavang & Makong & 25 & 29 & 56 & 3.0 & 9.2 & Old \\
\hline 14 & Sop On & Makong/Bo & 66 & 98 & 168 & 3.3 & 27.7 & Old \\
\hline- & $\mathrm{CaOy}$ & Makong & 26 & 30 & - & 10.5 & - & Old \\
\hline 15 & Done & Makong & 89 & 118 & 219 & 2.7 & 21.3 & Old \\
\hline 16 & Khone Khen & Makong & 37 & 44 & 64 & 2.0 & 27.7 & Old \\
\hline
\end{tabular}




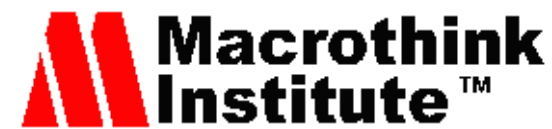

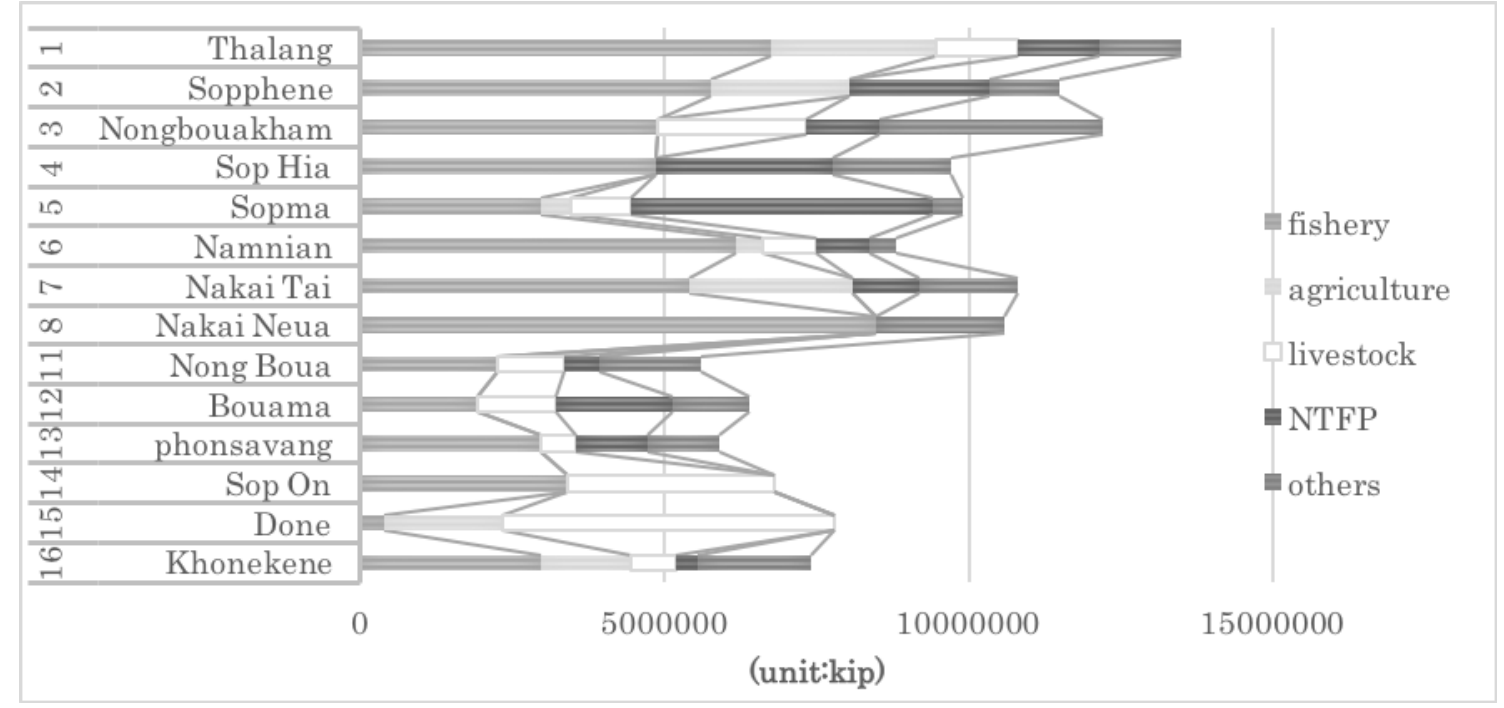

Figure 2. Income structure of 16 villages (based on interview with village head, 2014)

\subsection{Field Surveys}

Existing studies and reports were limited and, in particular, information about each village of the resettlement villages was scarce. Therefore, we conducted field studies in 2010, 2013, and 2014 focusing on the differences among villages. The first two studies were household questionnaire surveys implemented by the author who speaks Lao. The 2014 study was composed of interviews with the village head or vice-head from all 16 villages. The results are discussed in section 3 with reference to the project reports provided by the project authority as well as existing literature.

In the 2010 and 2014 surveys, questions were asked on specific topics including livelihoods and the cultural relationships between the independent and merged villages. In 2010, a survey of 135 households was conducted with residents from four villages (Boua Ma, Done, Sop On, and Ca Oy). Cay Oy had been split and merged with Done and Sop On. The sample included 50 families who lived in Boua Ma, 20 in Done, 30 in Sop On, and 35 in Ca Oy (4 families now live in Done and 31 live in Sop On). The 2013 survey of 60 households in two northern villages (Sop Phene and Sop Hia) looked into the causes of economic disparity between the two villages. The sample included 30 families from Sop Hia village and 30 from Sop Phene village, representing $70 \%$ and $53 \%$ of the total number of households, respectively. For both of the household questionnaire surveys, the interviewed households were recommended by the respective village heads with consideration of the feasibility of taking part in such a study during the survey periods.

In the 2014 study, the village head or vice-head from each of the 16 villages was interviewed in order to understand how reconstruction was progressing across the resettled villages. Interviews with staff of the resettlement management branch of the project authority were also conducted to collect information about the implementation of the livelihood reconstruction program. The interviews were semi-structured and conducted in Laotian with 
the assistance of interpreters. Questions focused on livelihood, including agriculture, livestock, fishery, and forestry, as well as other factors which are thought to be particularly related to the development of the villages according to the existing literature, such as education, social capital, access to markets, access to roads, and unique industries (Takesada, 2008; Fujikura \& Nakayama, 2013; Souksavath \& Maekawa, 2013; WB, 2014).

\subsection{Remote Sensing Analysis of Vegetation}

Although slash-and-burn agriculture is prohibited in the resettlement area, it was observed in multiple villages during the field surveys. Resettlers themselves implied that slash-and-burn agriculture did occur, but the information collected in the interviews was inadequate for analysis because they were reluctant to share much information about this topic. Because this information is important for understanding the livelihood status, we used remote sensing techniques to determine the location and size of the areas where slash-and-burn methods had been implemented. We considered several requirements in selecting satellite images: the minimum size of mesh to be able to identify the slash-and-burn areas; an adequate number of images through the slash-and-burn-season; the availability of images before the project; and the cost of acquisition. Then, we decided to use the LANDSAT images with a spatial resolution of 30 meters square and an interval of observance of 16 days across the study period. To compare land use before and after relocation occurred in 2008, images were obtained for the period from 2004 to 2015. Multiple satellites were in operation throughout this study period. Images from LANDSAT5 were used for the period from 2004 to 2011, images from LANDSAT7 were used for 2012 to 2013, and images from LANDSAT8 were used for 2014 to 2015.

The Normalized Differential Vegetation Index (NDVI) was applied to analyze annual changes in land use. To calculate NDVI, we divided the difference of infrared and red light spectra by the sum of both. This technique uses the high reflectance of leaves in near infrared spectra and their high absorbance of red light. The resulting NDVI takes a value between -1 and 1 , with a high NDVI value indicating high and active vegetative cover.

We collected images from February, when the dry weather provides images with less cloud, thus being more suitable for analysis. Because slash-and-burn is carried out in March, areas where the NDVI value decreased significantly, compared with neighboring domains or in comparison with the previous February, are considered as the areas where slash-and-burn agriculture had been performed. NDVI differences for those areas were visually confirmed. To extract those areas for further calculation, a threshold of NDVI difference was set each year by confirming the result visually. An area of 30 meters square ( $0.09 \mathrm{ha})$, equivalent to one pixel on the images, is too small for slash-and-burn agriculture which usually involves an area of at least $2 \mathrm{ha}$. Therefore, our analysis used areas of 90 meters square ( $0.81 \mathrm{ha})$ or larger, equivalent to $3 \times 3$ pixels. Using this procedure, the slash-and-burn agriculture activity can be determined and characterized at each village site. 


\section{Results: Problems Found in Resettled Villages}

\subsection{Sustainability of Income}

As shown in Table 2, in the survey of 135 households in 4 villages, all of the resettled residents said they had agreed to the resettlement plan, although some had been reluctant to do so. In addition, all of the households surveyed agreed that their economic condition was better than before resettlement and that they were satisfied with their new village site. In fact, according to the project report (NTPC, 2014), average per capita income increased from $110,000 \mathrm{kip} / \mathrm{month}$ in 1998 to $228,000 \mathrm{kip} /$ month in 2013, which is above the national poverty line of $186,000 \mathrm{kip} / \mathrm{month}$. Not only had income increased, but there was also high satisfaction with infrastructure improvements (Souksavath \& Nakayama, 2013). In 2013, the average income from different sectors across relocated villages was as follows. Income from fishing was highest, accounting for $38 \%$ of all income. This was followed by agriculture, which accounted for 20\%; wage labor, accounting for 17\%; and forestry, accounting for $16 \%$ (NTPC, 2014). Compared to the income structure before relocation, income from agriculture and livestock decreased: income from agriculture fell from $46 \%$ to $20 \%$ and livestock income declined from $23 \%$ to $5 \%$ (NTPC, 2014). According to resettled residents' statements, the underlying reason for the underperformance of agriculture was the poor soil quality in the allocated farmland. However, the project authority attributes it to the residents' lack of motivation to learn new agricultural skills suited to the soil quality of the resettled land. Forestry projects have not been in operation for several years. With respect to livestock, most large animals died due to disease and insufficient grazing land, and the provisioning of cows to each household as compensation was suspended out of concern about environmental disruption. Off-farm training, such as technology transfer and market tours, was conducted, but in most cases, the training was not fruitful.

Table 2. 2010 Survey Results: Agreement on the Resettlement Plan

\begin{tabular}{|c|c|c|c|c|c|c|c|c|}
\hline \multirow{2}{*}{$\begin{array}{l}\text { Did you ever agree to the } \\
\text { resettlement plan? }\end{array}$} & \multicolumn{2}{|c|}{$\begin{array}{l}\text { Воиа Мa } \\
(n=50)\end{array}$} & \multicolumn{2}{|c|}{$\begin{array}{l}\mathrm{Ca} O \mathrm{Oy} \\
(n=35)\end{array}$} & \multicolumn{2}{|c|}{$\begin{array}{l}\text { Done } \\
(n=20)\end{array}$} & \multicolumn{2}{|c|}{$\begin{array}{l}\text { Sop On } \\
(n=30)\end{array}$} \\
\hline & $\mathrm{HH}$ & $\%$ & $\mathrm{HH}$ & $\%$ & $\mathrm{HH}$ & $\%$ & $\mathrm{HH}$ & $\%$ \\
\hline Yes & 31 & 62 & 15 & 43 & 15 & 75 & 22 & 27 \\
\hline Yes, but reluctantly & 19 & 38 & 20 & 57 & 5 & 25 & 8 & 73 \\
\hline Don't agree & 0 & 0 & 0 & 0 & 0 & 0 & 0 & 0 \\
\hline
\end{tabular}

In consequence, agriculture had failed to become the major income source and resettled residents engaged in fishing more intensively in the newly created reservoir or restarted slash-and-burn agriculture to compensate for lower-than-planned income. In other words, resettled residents have managed to improve their post-resettlement living standards by themselves and it is notable that it has resulted in increased income for all the villages. On the other hand, residents are violating fishing regulations in some central and northern villages and engaging in slash-and-burn agriculture. Therefore, it is questionable if the increased 
income supported by intensive fishing and slash-and-burn agriculture will last long.

\subsection{Slash-and-burn implementation}

Some of the villages were provided 0.22 ha land by the project authority in addition to the $0.66 \mathrm{ha}$ originally assigned. This additional agricultural land is located in a formerly conserved forest area. However, during the field surveys it was observed that some resettled residents had restarted slash-and-burn agriculture. Therefore, decreases in forest area could be for either sedentary agriculture in the additional land or slash-and-burn agriculture. We identified the additional agricultural land based on the land use map of each village published by the project authority and using our analysis of the condition of the forest based on remote sensing images, we distinguished deforestation due to slash-and-burn from sedentary agriculture. The result is shown in Figure 3 where the horizontal axis shows the net area of forest decrease during four years and the vertical axis represents the proportion of the total deforested land area that is comprised of additional agricultural land. Villages on the right side of Figure 3 use larger areas for slash-and-burn agriculture, and villages in the upper part conduct more sedentary agriculture. The figure clearly shows that southern villages (which have poorer fishing conditions, as suggested in Figure 2) are conducting more slash-and-burn agricultural activity to make up for deficits in income. On the other hand, northern and central villages have a wider range of uses of additional agricultural land: villages with less non-farming income tend to cultivate additional land more intensively, yet there have also been observations that some households in those villages conduct slash-and-burn agriculture. Despite its being an illegal activity, slash-and-burn is conducted in some areas and has become an essential income source for some villagers whose income is lower than anticipated.

This situation is, however, possible only when the natural resource capacity exceeds demand. For the last 4 years, the observed average annual decrease in forest area was $1 \%$ of the total area of village forest, which can be considered lower than the maximum sustainable level for conducting slash-and burn agriculture with a 7-year span. However, there is a risk of overuse in some villages. In the village with the highest rate of forest decrease, the forest area decreased by $20 \%$ within four years. The head of another village remarked in the interview that they started slash-and-burn cultivation because they had heard other villages were doing the same. Inferring from this remark, underdeveloped villages may add slash-and-burn cultivation to their income generation. However, increased pressure on natural resources, particularly if accompanied by rapid population growth, will undermine the stock of natural resources. The slash-and-burn activities are currently an essential, but potentially unsustainable activity; thus, the project authority should recognize slash-and-burn as a formal income source in order to provide oversight of the activity. 


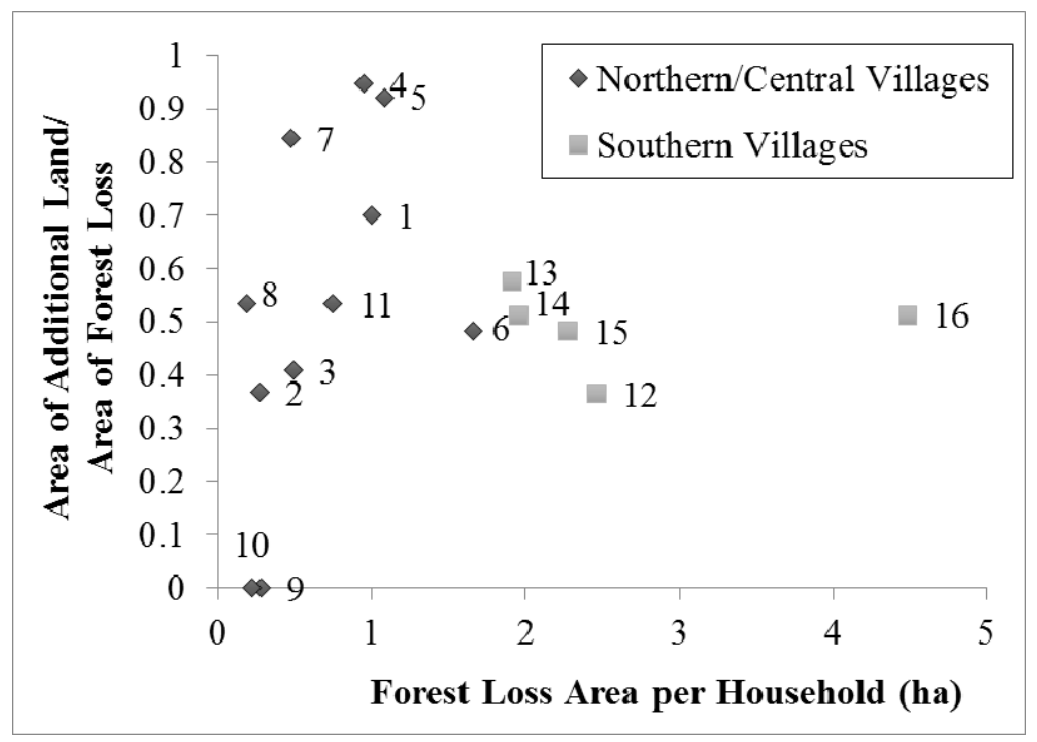

Figure 3. Comparison of forest loss among villages (Ando \& Sakamoto, 2015)

\subsection{Rapid Shift to Market Economy and Expansion of Disparity}

Although side effects of urbanization are generally inevitable in development projects, people resettled due to the NT2 project were obliged to change their lifestyle drastically because it was not a gradual process, but a sudden and irregular change in their social environment and sense of values. It is, of course, not easy to predict changes in social and economic environments because of uncertain external forces affecting development areas. In the case of this project, original expectations about the market and community turned out to be too optimistic. Many households suffered from loss of access to natural resources and increasing cash expenses due to the rapid shift to market economy. As those that are better off economically can better cope with unexpected social change, the effect of the dramatic social upheaval was more severe on originally poorer residents.

The scale of the effects varied depending on the location of the villages before and after resettlement. Before relocation, some villages were situated along roads, whereas others were set along rivers. Those villages originally situated along roads had better access to the market and had early exposure to the market economy, whereas villages located along rivers were almost entirely self-sufficient. Village location after relocation also matters, as roads to the southern villages are not as good as those to central and northern villages. Southern villages are still not easy to access, unlike central villages where the roads are connected to the outside; thus, the southern villages have a disadvantage in the shift to the market economy. On the other hand, whereas riverside villages resettled to the northern area gained better market opportunities and were forced to start new businesses to compete with established neighboring villages, southern villages were able to persist with their traditional lifestyle, namely slash-and-burn agriculture. In the short term, marketization was more favorable to villages originally located along roads before resettlement. 
In the case of fishery, the project authority set up fish markets in each village so that the resettled residents could sell fish easily. Many buyers gather at these markets because there is a stable and large fish supply from the nearby reservoir. However, the fish markets are functioning in only a few villages. In other villages, each household sells their fish individually, setting up their own stall or selling directly to stores in the district market. There are disparities in skills and networks for market activities derived from their livelihoods before the resettlement, making this another factor that can create inequalities among households and villages. This situation can be seen in other industries as well. Whereas some villages are benefitting from income from cattle, adjacent villages had trouble in selling cows. Intervention from outsiders affects natural resource management plans as well. Outsiders exploit fish and forest resources by buying illegal products, making it difficult to ascertain the actual state of natural resource use.

\subsection{Disputes between Villages}

Another issue in village resettlement is disputes between villages. Villages were originally interspersed along roads and rivers, but after relocation all villages were sited along roads, increasing both the land use density and the interaction among villages. The new locations afforded a chance to exchange information, practice cultural events on a larger scale, and expand access to markets and improved education. However, despite these potential benefits, relocation resulted in increased conflict between villages.

Some of the primary issues among villages arise from cultural differences. As the villages resettled, residents from one of the original 17 villages split and merged with two other villages, resulting in 16 villages after resettlement. Five years after resettlement, the 16 villages were reorganized into 10 villages, with six pairs of adjacent villages merging into six villages. Included were pairings of roadside villages and riverside villages. The villages in these pairings had different cultures and because roadside villages had disproportionately stronger political power, they also gained cultural and political dominance in the new villages.

Another issue is disputes over agricultural land near village boundaries. In some locations, villagers who have relatives in an adjacent village conduct agriculture together along the village borders. However, villages with fewer blood relations and less land tend to be involved in disputes over the scarce agricultural land. Although there are administrative village borders for village management, villagers are usually not aware of the village borders.

As issues related to cultural differences were predictable, the project authority conducted local consultations to guide resettlement site selection. By virtue of these consultations, village relations were good immediately after resettlement and no conflicts were observed even in the merged villages. But, as described above, more conflicts between the villages have happened through time. One shortcoming of the local consultations was the lack of consideration regarding the entire resettlement area as a whole. As a result of local priorities, the location of each village was decided primarily with the goal of being as close as possible to the original location. This policy of village siting based on local preference resulted in ethnically and culturally mixed village placement. Subsequently, the additional village 
mergers triggered more village disputes.

\section{Discussion}

Despite attempts to mitigate the effects of resettlement, such as local consultations and a livelihood reconstruction plan, resettlement still caused problems. The NT2 project demonstrates that even a carefully planned project can have unintended consequences. It may be impossible to make a perfect plan before resettlement; the challenge is to determine who should make any given decision and own its responsibility, and at which phase. This is a puzzle for the proper implementation of participatory development schemes that are a common requirement in recent development projects.

\subsection{Drawbacks of Participatory Decision Making in Determining Resettlement Locations}

The Social Reconstruction Plan was well elaborated and the project authority has made enormous efforts to achieve success with the project. However, a drawback of the plan was in the use of the participatory process for deciding on the location of the relocated villages. Because location is almost impossible to change after resettlement, site selection was one of the most important decisions, which became a root cause of other problems emerging afterward. It required building an early consensus among the resettlers, as well as between them and the project authority.

Because the resettlement scheme for the NT2 Dam project was intended to be a model case for future large dam projects, particular attention was given to obtaining consensus among residents affected by dam construction as one prerequisite in the WCD proposal. The household surveys and interviews with village heads indicate that resettled residents complained primarily about their lost land. The project authority notes that there was an option to move to another location downstream, where there is more arable land, but that the resettled residents themselves preferred to stay on the plateau where they felt spiritually connected. Therefore, the relocation site was selected by the resettlers despite the lack of availability of land and poor soil conditions. Why, then, did they select the poor land?

The household survey (Table 3) indicates that distance from the original settlement site was the most important factor for many resettled residents when it came to site selection. Contrary to this result, the result of another survey (Table 4) implies that place was not highly important for resettled residents compared with other factors such as housing and occupation. The reason why the priority was different in the two surveys is possibly because of the differences in ethnic composition of the surveyed villages. Because there was a high concern about the effects of this project on ethnic minorities, the project authority might have overweighted the opinions of minority groups despite ongoing assimilation of local people with mainstream Laotian culture. Another reason could be that the project authority used the opinions of resettled residents to justify the easiest option. As this project had only six years from the beginning of the contract to resettlement, cost and ease could have affected the choice of the resettlement site. There is no specific evidence to support this argument, but any public consultation bears such a potential risk.

In any case, project authorities should be held accountable for their decisions with respect to 
the purpose of the development and the desires of local residents. There is always a limitation on what can be covered in local consultation because of cost and time constraints. However, the critical elements of the development should be well elaborated by project authorities and the choice that they think the best should be presented along with necessary information for decision-making, possibly a scientifically sound one. On the other hand, if stakeholders want to make different decisions at their own cost, it should be noted that the consequences of such decisions are basically beyond the responsibility of project authorities. Otherwise, there may be no limits to the compensation duties of project authorities which, after all, would be covered by consumer costs or taxing of citizens without their knowledge.

\subsection{Classification of the Issues}

Figure 4 shows a summary of the results and discussion. It classifies the issues that arose during resettlement based on measures taken by the project authority. This model focuses on the risk forecast and local consultations before resettlement and is intended for analyzing the characteristics of each issue and whether they were possibly prevented or mitigated by any measures. The first branch classifies whether or not the risk was mentioned in the Social Development Plan (NTPC, 2005). The next branch identifies whether or not the topic was included in local consultations. Based on this model, problems in the resettlement program were categorized as one of three types.

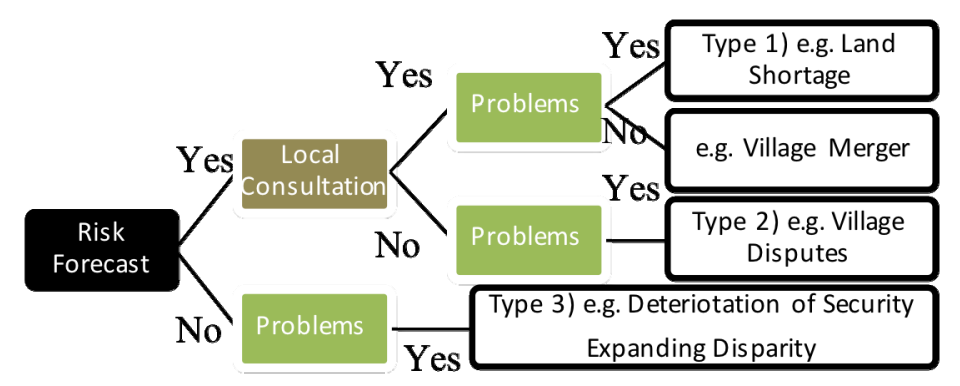

Figure 4. Decision tree for categorizing issues related to resettlement

\subsubsection{Type 1: Problems Predicted and Local Consultations Conducted}

This category includes problems that occurred even though they were anticipated and the opinions of local residents were collected. For example, land shortage is categorized here. There are several causes for this kind of issue. First, as was discussed in the previous section, the information provided as part of the local consultation was insufficient. Although villagers were informed that the land in the resettlement area was less fertile compared with other options, there were no data on harvest yields from each site or how livelihoods may be affected by lower yields. The loss of spiritual connections to their original homes was an obvious and imaginable risk which people were inclined to avoid. Second, the priorities of local residents easily change with time. At the time of local consultations, there might be many people who prioritize their tradition; however, with the passage of time, as younger 
generations grow to be a larger proportion of the population, and as with lived experience in a new location, the importance of proximity to the original home location may weaken.

\subsubsection{Type 2: Problems Predicted, but no Local Consultations Conducted}

There are also problems that were anticipated, but not discussed in local consultations. For example, an increase in the number of disputes between villages is categorized into this type. Although the ethnic and cultural differences among the villages was one of the major concerns that was to be addressed in the plan, local consultations only partially included this topic. The cases where villages were to merge were considered, but the influences of (and effects on) the villages which newly became neighbors across village boundaries were not considered. These problems were caused by the limited scope of local consultations.

\subsubsection{Type 3: Unexpected Problems}

A number of the problems identified occurred unexpectedly, such as the deterioration of social security and expanding disparities. In these cases, it is possible that the project authority itself may have been a cause of the issues, because these problems had not been included or monitored in the livelihood reconstruction plan. For this kind of social change, local residents are able to take countermeasures of their own. Therefore, companies should not try to predict and prevent these issues, but rather should prepare a flexible structure to incorporate endogenous countermeasures. Needless to say, capacity development of villagers is essential for them to be able to collaborate effectively with the project authority to overcome issues.

\section{Conclusion}

This paper describes the issues that arose in villages resettled for a dam construction project despite a carefully planned resettlement scheme with local participation. Issues were categorized into three types based on whether risks was identified before decision-making and whether appropriate mitigation measures were considered for the identified risks. As a result, it was found that local consensus could be contradictory to the best interests of residents in terms of development. Though the negative effect that might be caused by local consultation is limited, the use of local consultation should be planned and carried out carefully. For issues that cannot be solved by the efforts of residents after resettlement, including the siting of villages, more planning as well as a flexible system to incorporate endogenous solutions is required, instead of complex and fixed plans applied uniformly across all the villages. The findings and lessons from this study can be applied to other projects, not only limited to development projects in developing countries, but also problems including involuntary resettlement, such as relief for climate change immigrants, and compensation for resettlers due to infrastructure development or massive regional accidents. As we have discussed in this paper, the resettlement site selection is a crucial issue in these cases. It is often recommended that places be prepared for resettlers close to their original residences and that resettlers' voices be respected as part of the process of participatory decision-making. However, plans may not work as expected and it is crucial to clarify the responsibility for and possible consequences of the decisions when they are implemented. 
Otherwise, they may not only harm the people concerned, but also burden the society with compensation costs, with no end in sight.

\section{Acknowledgements}

The authors would like to acknowledge with sincere appreciation that field research projects for this paper were supported by Dr. Keophousone Phonhalath and Dr. Phetnakhone Xaixongdeth of the National University of Laos, and the Nakai Resettlement Office of NTPC. Funding from KAKENHI (26550108) is gratefully acknowledged.

\section{References}

Ando, S., \& Sakamoto, M. (2015). Causes of income inequality among the villages involuntarily resettled for the Nam Theun 2 Hydropower Project. Papers on Environmental Information Science, 29, 333-338. (In Japanese) http://doi.org/10.11492/ceispapers.ceis $29.0 \_333$

Fujikura, R., \& Nakayama, M. (2013). The long-term impacts of resettlement programmes resulting from dam construction projects in Indonesia, Japan, Laos, Sri Lanka and Turkey: A comparison of land-for-land and cash compensation schemes. International Journal of Water Resources Development, 29(1), 4-13. https://doi.org/10.1080/07900627.2012.741032

Matsumoto, I., \& Harashina, Y. (2012). Effects of livelihood restoration plans on dam project: Peoples' livelihoods changes by the Nam Theun 2 Hydropower Project in Lao PDR. Japan Society for Impact Assessment, 10(2), 65-76. (In Japanese)

Mcdowell, D. K., Scudder, T., \& Lee, T. M. (2015). Lao People's Democratic Republic Nam Theun 2 Multipurpose Project: twenty fourth report of the international and social panel of experts. Washington, D.C.: World Bank Group. http://documents.worldbank.org/curated/en/2015/11/25238157/lao-peoples-democratic-republ ic-nam-theun-2-multipurpose-project-twenty-fourth-report-international-social-panel-experts.

Nam Theun 2 Power Company [NTPC]. (2005). Nam Theun 2 Social Development Plan: Nakai Plateau and EMDP and RAP. NTPC, Vol. 2, chapter 16. Vientiane: Nam Theun 2 Power Company, Lao PDR.

Nam Theun 2 Power Company [NTPC]. (2008). Health checks and surveys for resettled populations. Vientiane: Nam Theun 2 Power Company, Lao PDR.

Nam Theun 2 Power Company [NTPC]. (2014). Nakai Resettlers' reality: From the past to the future. Vientiane: Nam Theun 2 Power Company, Lao PDR.

Porter, I. C., \& Shivakumar, J. (2010). Doing a dam better: The Lao People's Democratic Republic and the story of Nam Theun 2 (NT2). Washington, DC: World Bank. http://documents.worldbank.org/curated/en/200041468044952974/Doing-a-dam-better-the-L ao-Peoples-Democratic-Republic-and-the-story-of-Nam-Theun-2-NT2

Souksavath, B., \& Maekawa, M. (2013). The livelihood reconstruction of resettlers from the Nam Ngum 1 hydropower project in Laos. International Journal of Water Resources 


\section{Macrothink}

Journal of Asian Development

ISSN 2377-9594

2017, Vol. 3, No. 2

Development, 29(1), 59-70. https://doi.org/10.1080/07900627.2012.738592

Souksavath, B., \& Nakayama, M. (2013). Reconstruction of the livelihood of resettlers from the Nam Theun 2 hydropower project in Laos. International Journal of Water Resources Development, 29(1), 71-86. https://doi.org/10.1080/07900627.2012.738792

World Bank. (2004). Involuntary resettlement source book-Planning and implementation in development projects. Washington, DC: World Bank. http://documents.worldbank.org/curated/en/206671468782373680/Involuntary-resettlement-s ourcebook-planning-and-implementation-in-development-projects

World Bank. (2011). Laos-Nam Theun 2 Hydropower Project: Tenth report of the International Advisory Group (IAG): handing over. Washington, DC: World Bank. http://documents.worldbank.org/curated/en/867971468299207238/Laos-Nam-Theun-2-Hydr opower-Project-Tenth-report-of-the-International-Advisory-Group-IAG-handing-over

World Bank. (2014). Laos-Nam Theun 2 Multipurpose Development Project: Twenty second report of the environmental and social panel of experts. Washington, DC: World Bank. http://documents.worldbank.org/curated/en/935151468263930670/Laos-Nam-Theun-2-Multi purpose-Development-Project-twenty-second-report-of-the-environmental-and-social-panel-o f-experts

World Commission on Dams [WCD]. (2000). Dams and development: A new framework for decision-making. Earthscan Publications Ltd., London.

\section{Copyright Disclaimer}

Copyright reserved by the author(s).

This article is an open-access article distributed under the terms and conditions of the Creative Commons Attribution license (http://creativecommons.org/licenses/by/4.0/). 